The Narrative Shape of Truth 


\title{
Literature and Philosophy
}

\author{
A. J. Cascardi, General Editor
}

This series publishes books in a wide range of subjects in philosophy and literature, including studies of the social and historical issues that relate these two fields. Drawing on the resources of the Anglo-American and Continental traditions, the series is open to philosophically informed scholarship covering the entire range of contemporary critical thought.

ALREADY PUBLISHED:

J. M. Bernstein, The Fate of Art: Aesthetic Alienation from Kant to Derrida and Adorno

Peter Bürger, The Decline of Modernism

Mary E. Finn, Writing the Incommensurable: Kierkegaard, Rossetti, and Hopkins

Reed Way Dasenbrock, ed., Literary Theory After Davidson

David P. Haney, William Wordsworth and the Hermeneutics of Incarnation

David Jacobson, Emerson's Pragmatic Vision: The Dance of the Eye

Gray Kochhar-Lindgren, Narcissus Transformed: The Textual Subject in Psychoanalysis and Literature

Robert Steiner, Toward a Grammar of Abstraction: Modernity, Wittgenstein, and the Paintings of Jackson Pollock

Sylvia Walsh, Living Poetically: Kierkegaard's Existential Aesthetics

Michel Meyer, Rhetoric, Language, and Reason

Christie McDonald and Gary Wihl, eds., Transformations in Personhood and Culture After Theory

Charles Altieri, Painterly Abstraction in Modernist American Poetry: The Contemporaneity of Modernism

John C. O'Neal, The Authority of Experience: Sensationist Theory in the French Enlightenment

John O'Neill, ed., Freud and the Passions

Sheridan Hough, Nietzsche's Noontide Friend: The Self as Metaphoric Double

E. M. Dadlez, What's Hecuba to Him? Fictional Events and Actual Emotions

Hugh Roberts, Shelley and the Chaos of History: A New Politics of Poetry

Charles Altieri, Postmodernisms Now: Essays on Contemporaneity in the Arts

Arabella Lyon, Intentions: Negotiated, Contested, and Ignored

Jill Gordon, Turning Toward Philosophy: Literary Device and Dramatic Structure in Plato's Dialogues

Michel Meyer, Philosophy and the Passions: Toward a History of Human Nature. Translated by Robert F. Barsky

Reed Way Dasenbrock, Truth and Consequences: Intentions, Conventions, and the New Thematics

David P. Haney, The Challenge of Coleridge: Ethics and Interpretation in Romanticism and Modern Philosophy

Alan Singer, Aesthetic Reason: Artworks and the Deliberative Ethos

Tom Huhn, Imitation and Society: The Persistence of Mimesis in the Aesthetics of Burke, Hogarth, and Kant Jennifer Anna Gosetti-Ferenci, The Ecstatic Quotidian: Phenomenological Sightings in Modern Art and Literature Max Statkiewicz, Rhapsody of Philosophy: Dialogues with Plato in Contemporary Thought

David N. McNeill, An Image of the Soul in Speech: Plato and the Problem of Socrates

Alan Singer, The Self-Deceiving Muse: Notice and Knowledge in the Work of Art

Chad Wellmon, Becoming Human: Romantic Anthropology and the Embodiment of Freedom 


\section{The}

\section{Narrative Shape of Truth}

Veridiction in Modern European Literature

Ilya Kliger

The Pennsylvania State University Press

University Park, Pennsylvania 


\section{Library of Congress Cataloging-in-Publication Data}

Kliger, Ilya.

The narrative shape of truth : veridiction in modern European literature / Ilya Kliger.

p. $\quad \mathrm{cm}$. - (Literature and philosophy)

Summary: "Draws on philosophical and novelistic texts from the Western European and Russian canons to explore a crucial moment in the epistemological history of narrative and present a nonreductive way of conjugating the histories of philosophy and the novel"-Provided by publisher. Includes bibliographical references and index. ISBN 978-0-27I-03798-I (cloth : alk. paper)

I. European fiction-History and criticism. 2. Truth in literature.

3. Fictions, Theory of.

4. Literature-Philosophy.

5. Narration (Rhetoric).

I. Title.

$$
\begin{aligned}
& \mathrm{PN}_{3347 .} \mathrm{K}_{55} 2 \mathrm{OII} \\
& 809^{\prime} .93353-\mathrm{dc22} \\
& 2010041918
\end{aligned}
$$

Copyright (C) 20II The Pennsylvania State University All rights reserved

Printed in the United States of America Published by The Pennsylvania State University Press, University Park, PA I6802-1003

The Pennsylvania State University Press is a member of the Association of American University Presses.

It is the policy of The Pennsylvania State University Press to use acid-free paper. Publications on uncoated stock satisfy the minimum requirements of American National Standard for Information Sciences-Permanence of Paper for Printed Library Material, ANsI Z39.48-I992.

This book is printed on Natures Natural, which contains $50 \%$ post-consumer waste. 